\title{
PENGEMBANGAN CONTENT MANAGEMENT SYSTEM PADA ADMISI ONLINE BINUS UNIVERSITY
}

\author{
Karto Iskandar; Jefriyanto; Halena Giovanni; Candra Gunawan \\ Computer Science Department, School of Computer Science, Binus University \\ Jl. K.H. Syahdan No. 9, Palmerah, Jakarta Barat 11480 \\ karto_i@binus.edu; jefri.08@gmail.com; halquelin@gmail.com; hell_buster90@yahoo.com
}

\begin{abstract}
Technically registration form for new Binus institution must be regenerated and not dynamic. Therefore, this research is objected to simplify the creation of registration process for new Binus institution and provide solutions to the problem when Binus establish other new institutions. Methodology used is analysis and design of the database (database oriented). Analysis is done by asking the problems of existing systems in the IT Directorate, whereas the design uses UML diagram notation 2.0. The results obtained is front end and back end applications for the Content Management System of the registration form. The results of this design can be used to simplify the new student registration or in the many Binus institutions by grouping similar fields. With some changes in the front end and back end applications for content Management System, the addition of new online admission application form can be managed faster, where the creation of admision registration form is managed in the back end application. As suggestions for future development, online admission registration can be run in mobile version.
\end{abstract}

Keywords: sytem information development, content management system, online registration

\begin{abstract}
ABSTRAK
Penambahan formulir pendaftaran bagi instansi baru secara teknis harus dibuat ulang dan tidak dinamis. Maka dari itu, penelitian bertujuan untuk mempermudah pembuatan proses pendaftaran bagi instansi baru Binus dan memberikan solusi dari permasalahan penambahan instansi baru tersebut. Metodologi yang digunakan adalah analisis dan perancangan berbasis database (database oriented). Analisis dilakukan dengan menanyakan cara kerja dan permasalahan sistem yang berjalan pada IT Directorate Binus. Sedangkan perancangan menggunakan diagram UML dengan notasi 2.0. Hasil yang dicapai berupa aplikasi front end dan aplikasi back end untuk manajemen formulir pendaftaran. Hasil dari perancangan ini dimanfaatkan untuk kemudahan pendaftaran mahasiswa baru di berbagai instansi Binus dengan mengelompokkan beberapa field sejenis. Dengan perubahan pada aplikasi front end dan penambahan aplikasi back end untuk sistem manajemen konten, penambahan formulir pendaftaran baru pada admisi online menjadi lebih cepat, di mana pembuatan formulir instansi baru akan diatur pada aplikasi back end. Sebagai saran untuk pengembangan kedepannya, pendaftaran admisi online dapat dilakukan dalam versi mobile.
\end{abstract}

Kata kunci: pengembangan sistem informasi, sistem manajemen konten, admisi online 


\section{PENDAHULUAN}

Salah satu Perguruan Tinggi yang mengimplementasikan internet pada pendaftaran calon mahasiswa baru adalah Binus University. Binus University menyadari pentingnya proses marketing dan admisi sebagai ujung tombak dalam persaingan pada era globalisasi ini guna menuju visi-nya sebagai world class Univerisity. Di dalam Binus University sistem pendaftaran online ini dapat dilakukan pada website admisi online dengan alamat http://www.binus.ac.id/daftaronline. Di dalam Binus University, terdapat pula Binus Regular, Binus International, Binus Online Learning, dan High School Enrichment Program (HSEP) juga memiliki sistem pendaftaran online ini. Dengan perkembangan jaman dan tuntutan industri tidak menutup kemungkinan akan bertambah instansiinstansi lain setingkat dikemudian hari.

Permasalahan yang sering muncul saat ini adalah dengan penambahan instansi tersebut diperlukan pembuatan sistem baru untuk mendukung proses operasionalnya. Salah satunya adalah proses daftar online pada admisi. Untuk sistem yang berjalan pada saat ini, penambahan formulir pendaftaran online instansi tersebut dilakukan dengan membuat ulang formulir yang secara teknis memakan waktu, di mana masing-masing instansi memiliki model proses yang hampir sama dengan tingkat ragam variasi hanya mencapai $10 \%-20 \%$. Selain itu, pada sistem pengisian formulir saat ini, field yang harus diisi banyak. Formulir tersebut terdiri dari tiga halaman dengan total field yang harus diisi sebanyak \pm 100 field pada rata-rata instansi Binus yang ada. Hal ini, memberi dampak pada waktu pengisian formulir. Permasalah utamanya adalah tidak adanya Sistem Managemen Konten pada Admisi Online Binus University.

Peneliti mengembangkan admisi online melalui inovasi sesuai dengan perkembangan teknologi saat ini. Inovasi yang dilakukan yaitu dengan Mempersingkat cara penambahan dan pengubahan formulir pada instansi Binus melalui back end dengan sistem manajemen konten tanpa harus melakukan coding. Termasuk penambahan tabel-tabel baru dan relasinya. Mempersingkat cara pengisian formulir pendaftaran dengan cara mengelompokkan field-field sejenis. Tujuan yang akan dicapai pada penelitian ini adalah Kemudahan proses penambahan formulir pendaftaran mahasiswa pada setiap instansi Binus yang baru. Pengisian formulir pendaftaran yang lebih ringkas bagi pendaftar. Manfaat yang didapatkan adalah waktu dalam proses pembuatan formulir online untuk instansi Binus baru yang lebih cepat. Mempercepat waktu pengisian formulir pendaftaran.

\section{METODE}

Penelitian dilakukan menggunakan metodologi berikut: (1) Analisis, dilakukan dengan tahapan sebagai berikut: (a) survei atau obervasi atas sistem yang sedang berjalan, dilakukan dengan meminta informasi dan data mengenai kondisi, cara kerja dan permasalahan sistem pada pihak IT Directorate Binus yang menangani langsung kebutuhan admisi online; (b) wawancara kepada pihak IT Directorate divisi Marketing mengenai detail kondisi, cara kerja, dan permasalahan sistem pada pihak IT Directorate Binus yang menangani langsung kebutuhan admisi online; (c) studi pustaka melalui buku-buku dan jurnal ilmiah yang berkaitan dengan topik yang dibahas; (2) perancangan, pertamatama dilakukan pembuatan model proses waterfall. Hal ini dikarenakan tahap demi tahap yang dilalui harus menunggu selesainya tahap sebelumnya dan berjalan berurutan. Model proses terdiri dari tahapan sebagai berikut: (a) system information engineering and modeling - kebutuhan dari keseluruhan sistem admisi online didapatkan melalui wawancara kepada pihak IT Directorate Binus; (b) software requirement analysis - kebutuhan dari admisi online difokuskan pada penambahan instansi Binus yang baru, proses pengisian formulir calon mahasiswa baru dan implementasi personalisasi pada halaman setelah login; (3) design - pada proses ini, dilakukan perancangan 
database yang mengacu pada Connolly dan Begg dan juga perancangan user interface untuk memenuhi kebutuhan sistem yang akan dibuat; (4) coding - bahasa pemrograman yang digunakan pada sistem admisi online adalah ASP .NET C\# 3.5 dengan DBMS Microsoft SQL Server 2005. Untuk personalisasi, tools yang digunakan adalah tools Dropthings; (5) testing verification - pada tahap testing/ verification, langkah pertama yang dilakukan berupa membuat instansi Binus yang baru dengan sistem CMS. Lalu mengisi formulir yang sudah dipisahkan berdasarkan prioritas, baik sebelum login ataupun setelah login. Terakhir, melakukan testing halaman yang telah mengimplementasikan personalisasi. Selanjutnya dibuat notasi perancangan menggunakan UML 2.0 yang mengacu pada standar perancangan Roger S. Pressman (2006).

\section{Model Waterfall}

Berikut adalah penjelasan dari tahap-tahap yang dilakukan di dalam model waterfall (Gambar 1): (1) Communication. Permodelan ini diawali dengan komunikasi dan kolaborasi dengan konsumen (stackholders) untuk mencari kebutuhan dari keseluruhan sistem yang akan diaplikasikan ke dalam bentuk software. Hal ini sangat penting, mengingat software harus dapat berinteraksi dengan elemenelemen yang lain seperti hardware, database, dsb. Tahap ini sering disebut dengan Project Definition; (2) Planning. Proses ini menetapkan rencana untuk pengerjaan software yang meliputi : tugas-tugas teknis yang akan dilakukan, resiko yang mungkin tejadi, sumber-sumber yang dibutuhkan, hasil yang akan dibuat, dan jadwal pengerjaan; (3) Modeling. Proses ini meliputi pembuatan model yang memungkinkan pengembang dan konsumen untuk lebih memahami kebutuhan perangkat lunak dan desain yang akan mencapai kebutuhan tersebut; (4) Construction. Proses ini merupakan proses gabungan dari coding dan testing. Untuk dapat dimengerti oleh mesin computer, maka desain tadi harus diubah bentuknya menjadi bentuk yang dapat dimengerti oleh mesin, yaitu ke dalam bahasa pemrograman melalui proses coding.

Tahap ini merupakan implementasi dari tahap design yang secara teknis nantinya dikerjakan oleh programmer. Sedangkan testing adalah sesuatu yang dibuat haruslah diujicobakan. Demikian juga dengan software. Semua fungsi-fungsi software harus diujicobakan, agar software bebas dari error, dan hasilnya harus benar-benar sesuai dengan kebutuhan yang sudah didefinisikan sebelumnya; (5) Deployment. Pemeliharaan suatu software diperlukan, termasuk di dalamnya adalah pengembangan, karena software yang dibuat tidak selamanya hanya seperti itu. Ketika dijalankan mungkin saja masih ada error kecil yang tidak ditemukan sebelumnya, atau ada penambahan fitur-fitur yang belum ada pada software tersebut. Pengembangan diperlukan ketika adanya perubahan dari eksternal perusahaan seperti ketika ada pergantian sistem operasi, atau perangkat lainnya.

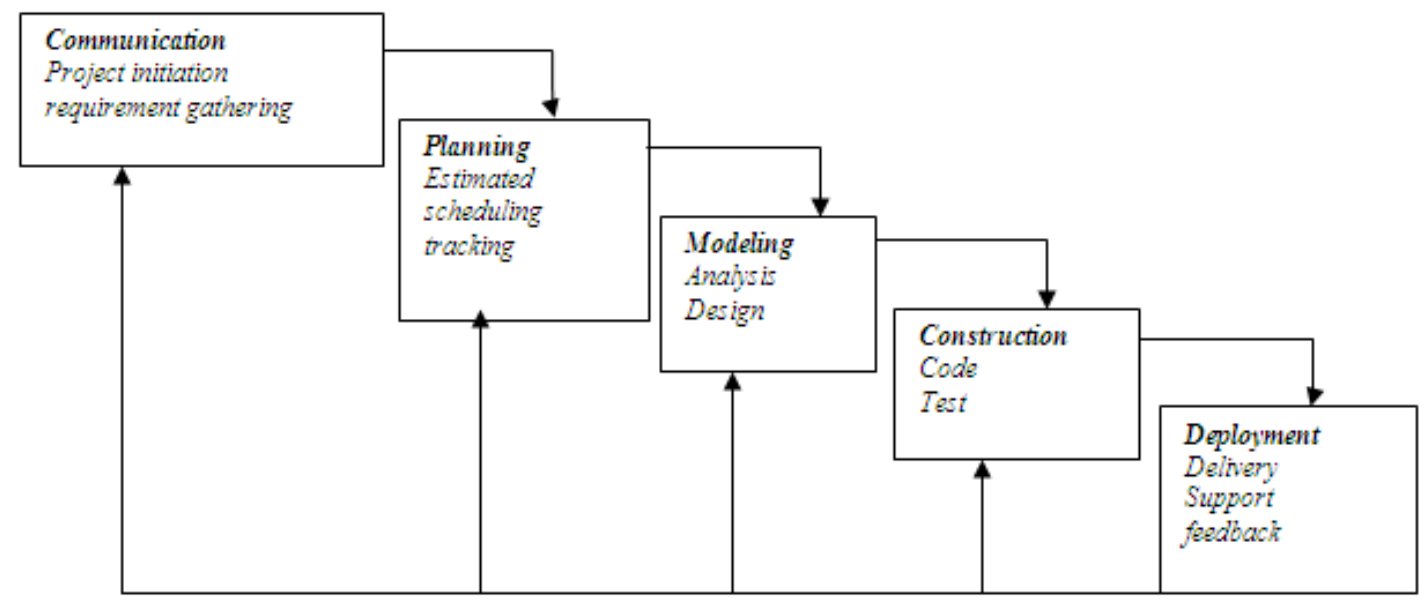

Gambar 1. Waterfall model. 


\section{Teori Basis Data}

Data, menurut Connolly dan Begg (2004, p20) adalah komponen yang paling penting dalam Database Management System, berasal dari sudut pandang pengguna akhir. Data bertindak sebagai jembatan yang menghubungkan antara mesin dengan user. Menurut Hoffer, Prescott, Topi $(2009, \mathrm{p} 7)$, basis data adalah sebuah kumpulan yang terorganisir dari data yang berhubungan secara logika, yang mungkin ukurannya berbagai jenis dan mempunyai kerumitan rtian Basis Data. Menurut Connolly dan Begg (2004, p15), basis data adalah koleksi atau kumpulan data yang saling berhubungan secara logis, yang dirancang untuk dapat memenuhi kebutuhan sistem dari sebuah organisasi. Kelebihan basis data adalah dapat digunakan secara bersamaan oleh banyak pengguna. Selain itu semua data terintegrasi, sehingga mengurangi jumlah penduplikasian data.

\section{Use Case Diagram}

Menurut Bennett, Skelton, dan Lunn (2005, p20), use case diagram merepresentasikan rangkaian dari actions yang terlibat dalam sistem, dan actors mewakilkan orang atau sistem lain yang berinteraksi dengan sistem yang sedang dimodelkan. Diagram use case didukung oleh tingkah laku yang spesifik, dimana mendefinisikan interaksi di dalam sebuah bagian use case. Actors dan use case adalah dua elemen utama dalam deskripsi. Aktor dan use case dapat terhubung satu sama lainnya, dan dapat saling melengkapi dalam struktur use case diagram.

\section{Rich Picture}

Rich Picture adalah gambaran informal yang menggambarkan situasi yang dipahami atau dimengerti oleh pelukis. Dengan Rich Picture kita diarahkan untuk memahami dan merasakan kepentingan dari aspek tersebut. Rich Picture digunakan dalam seleksi sistem untuk menunjukkan semua persepsi yang dihadapi dalam pengembangan sistem (Mathiassen, 2000, p26).

Untuk menggambar Rich Picture tidaklah mudah. Langkah pertama adalah menggambar entitas-entitas penting seperti pelaku, objek fisik, tempat, organisasi, kebutuhan dan pekerjaan. Pelaku kebanyakan berada di tengah Rich Picture, pelaku ini dapat merupakan pelanggan, pengguna sistem, pengembang sistem, ataupun pelaku lain yang mempunyai bagian dalam Rich Picture. Objek fisik dapat berupa benda atau barang apapun. Dalam suatu pabrik, akan terdapat mesin atau peralatan ataupun persediaan yang ada di gudang. Dalam kantor administrasi, objek dapat berupa dokumen atau formulir.

Tempat menunjukkan lokasi dari pelaku dan benda. Organisasi dapat merupakan keseluruhan dari perusahaan, divisi yang ada diperusahaan, atau proyek yang melibatkan perusahaan. Kebutuhan dan pekerjaan berhubungan dengan pelaku dalam organisasi dan menunjukkan kewajiban mereka dalam perusahaan. Pemilik permasalahan dapat dimasukkan dalam Rich Picture. Pemilik permasalahan adalah pelaku yang mengidentifikasi masalah, baik secara langsung maupun tidak langsung. Pelanggan adalah salah satu dari pemilik permasalahan, tetapi kelompok pengguna, manajer, dan pengembang sistem sendiri merupakan pemilik permasalahan yang potensial. Fokus kepada pemilik permasalahan dapat mengarahkan ke banyak cara untuk memahami situasi yang terjadi. Walaupun pemilik permasalahan mempunyai pendapat sesuai pemikiran mereka, tetapi Rich Picture tidak dapat semudah itu untuk memecahkan masalah sesuai sama seperti pemikiran pemilik permasalahan tersebut. 


\section{HASIL DAN PEMBAHASAN}

\section{Prosedur Penambahan Formulir}

Pada bagian back end terdapat berbagai fitur pengaturan konten yang terdiri dari: Home, Registration (Change Data Approval, Information Booking, Registrant, Pembatalan E-Commerce, Credit Card Payment Report, Klikbca Payment Report, ATM Payment Report, Report MiGS), Generate Form, Entrance Test. Entrance Test, Entrance Test Result), Re-Registration(Detail ReRegistration, View Registrant), FAQ and Messages (FAQ Management, Quetion Management, Private Messages), Management Setting (Main Setting, Announcement), Scholarship Registrant, User Management (Create New User, Change Password, Email Notification Management, Menu Management), Content Management (Edit Content, Edit General Guidelines), dan HSEP Quota. Apabila terdapat penambahan formulir baru, prosedur tersebut masih dilakukan secara manual.

Mula-mula, prosedur yang dilakukan adalah penambahan jenis formulir baru oleh Manager Marketing. Setelah itu, staff Marketing memberitahukan kepada pihak IT Directorate perihal field apa saja yang dibutuhkan dalam pendaftaran jenis formulir yang baru ini. Setelah itu pihak IT akan menganalisis dan membuat rancangan serta membuat program untuk formulir pendaftaran baru. Setelah satu jenis formulir pendaftaran yang baru selesai dibuat, maka akan dilakukan testing oleh pihak IT untuk menguji kesesuaian dari sistem yang sudah dibuat. Gambar Rich Picture untuk Prosedur Penambahan Formulir bagi institusi Binus baru dapat dilihat pada Gambar 2.

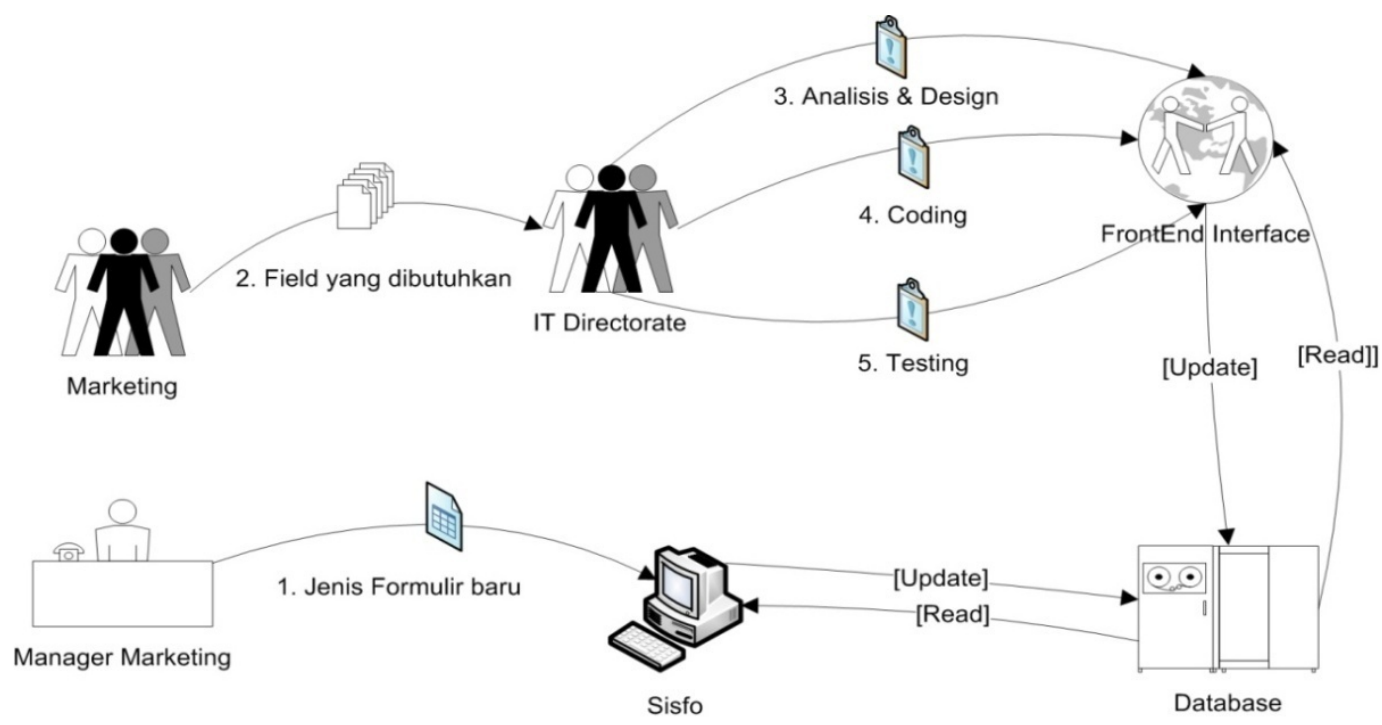

Gambar 2. Rich picture penambahan formulir.

Rancangan tampilan halaman setelah login secara keseluruhan terdiri dari pemilihan widget dari daftar widget yang tersedia. Kemudian di bawahnya terdapat fitur timeline registration yang relevan dengan langkah yang harus ditempuh oleh pendaftar beserta perinciannya. Di bawah dari timeline registration terdapat susunan widget yang letaknya dapat dipersonalisasikan oleh pendaftar. Gambar rancangan tampilan halaman setelah login dapat dilihat pada Gambar 2.

Tabel 1 adalah perhitungan waktu yang dibutuhkan untuk melakukan masing-masing proses dari prosedur penambahan formulir baru. 
Tabel 1

Prosedur Penambahan Formulir (Sistem yang Sedang Berjalan)

\begin{tabular}{lcl}
\multicolumn{1}{c}{ Proses } & $\begin{array}{c}\text { Waktu yang } \\
\text { Dibutuhkan }\end{array}$ & \multicolumn{1}{c}{ Pelaksana } \\
\hline Penambahan instansi baru & \pm 10 menit & Manager Marketing \\
\hline Analisis field yang dibutuhkan & $\pm 1,5$ minggu & IT Directorate dan Marketing \\
\hline Design & $\pm 0,5$ minggu & IT Directorate \\
\hline Coding & $\pm 1,5$ bulan & IT Directorate \\
\hline Testing & \pm 2 minggu & IT Directorate \\
\hline
\end{tabular}

\section{Tahapan Pendaftaran}

Pada halaman pertama yang terdiri 12 field yang dibutuhkan untuk diisi oleh calon pendaftar yaitu Lokasi, Nama Calon Mahasiswa, No KTP/No Pelajar, No Telp, Mobile Number, E-Mail, field Pembeli/Buyer berupa Nama Pembeli, Alamat, No KTP/No Pelajar, No Telp, Mobile Number, dan EMail. Selanjutnya, halaman kedua masing-masing instansi terdapat perbedaan field yang harus diisi. Halaman kedua Binus Regular terdiri dari 36 field, yaitu Gelombang Pendaftaran, Nama Ayah, Nama Ibu, Nama Wali, Nama Calon Mahasiswa, Jalur Pendaftaran, Jenis Beasiswa, Jenis Kerjasama, Jenis SMTA, Fakultas, Jurusan, Jenjang, Peminatan, Shift Kuliah, Tempat Lahir, Tanggal Lahir, Alamat EMail, Jeni Kelamin, Kewarganeagaraan, Agama, Status Kerja, Status Perkawinan, Alamat Lengkap, Nomor Rumah, RT, RW, Kota, Kode Pos, Kode Area - No. Telp, Mobile Number 1, Mobile Number 2, Mobile Number 3, Nama Sekolah SMTA, Alamat Sekolah SMTA, Kota Tempat SMTA, dan Formal Foto $(3 \times 4)$.

Sedangkan Halaman kedua Binus International terdapat 40 field, yaitu Gelombang Pendaftaran, Nama Ayah, Mobile Number Ayah, Pekerjaan Ayah, Nama Ibu, Nama Wali, Nama Calon Mahasiswa, Jalur Pendaftaran, Jenis Beasiswa, Jenis Kerjasama, Jenis SMTA, Fakultas, Jurusan, Jenjang, Peminatan, Shift Kuliah, Tempat Lahir, Tanggal Lahir, Alamat E-Mail, Jenis Kelamin, Kewarganeagaraan, Agama, Status Kerja, Status Perkawinan, Alamat Lengkap, Nomor Rumah, RT, RW, Kota, Kode Pos, Kode Area - No Telp, Mobile Number 1, Mobile Number 2, Mobile Number 3, Nama Sekolah SMTA, Alamat Sekolah SMTA, Kota Tempat SMTA, Formal Foto $(3 \times 4)$, TOEFL, dan Nama Institusi.

Sedangkan halaman kedua untuk Binus Online Learning terdapat 61 field, yaitu Gelombang Pendaftaran, Nama Ayah, Pekerjaan Ayah, Nama Perusahaan Ayah, Nama Ibu, Pekerjaan Ibu, Nama Perusahaan Ibu, Nama Calon Mahasiswa, Jalur Pendaftaran, Jenis Beasiswa, Jenis Kerjasama, Pendidikan, Fakultas, Jurusan, Jenjang, Peminatan, Shift Kuliah, Tempat Lahir, Tanggal Lahir, Alamat E-Mail, Jenis Kelamin, Kewarganeagaraan, Agama, Status Kerja, Status Perkawinan, Alamat Lengkap, Nomor Rumah, RT, RW, Kota, Kode Pos, Kode Area - No Telp, Mobile Number 1, Mobile Number 2, Mobile Number 3, Nama Pendidikan, Alamat Pendidikan, Kota Tempat Pendidikan, field Data Pekerjaan berupa Status Kerja, Jabatan, Nama Perusahaan, Alamat Perusahaan, Nomor Perusahaan, RT, RW, Kota, Kode Pos, Kode Area - No Telp, Kode Area - No Fax, Alamat Penyuratan, field Data Pendidikan Formal yang terdiri dari Nama Universitas, Program Studi, Gelar Keserjanaan, Tahun Kelulusan, IPK S1, dan field Pengalaman Kerja yang terdiri dari Nama Perusahaan, Posisi, Bagian, Tingkat, Tahun Kerja, Formal Foto $(3 \times 4)$.

Setelah itu, calon pendaftar diminta mengisi formulir halaman ketiga. Untuk Binus Regular, Binus International, dan Binus Online Learning formulir halaman ketiganya terdiri dari 57 field, yaitu Keadaan Ayah, Nama Ayah, Alamat Lengkap, Nomor Rumah, RT, RW, Kota, Kode Pos, Kode Area No Telp Ayah, No Handphone Ayah, Kode Area - No Fax, Alamat e-mail Ayah, Provinsi Tempat Tinggal, Kota/Kabupaten Tempat Tinggal, Negara Tempat Tinggal, Pekerjaan Ayah, Jabatan 
Pekerjaan, Nama Perusahaan, Pendidikan Ayah, Keadaan Ibu, Nama Ibu, Alamat Lengkap, Nomor Rumah, RT, RW, Kota, Kode Pos, Kode Area - No Telp Ibu, No Handphone Ibu, Kode Area - No Fax, Alamat e-mail Ibu, Provinsi Tempat Tinggal, Kota/Kabupaten Tempat Tinggal, Negara Tempat Tinggal, Pekerjaan Ibu, Jabatan Pekerjaan, Nama Perusahaan, Pendidikan Ibu, Nama Wali, Alamat Lengkap, Nomor Rumah, RT, RW, Kota, Kode Pos, Kode Area - No Telp Wali, No Handphone Wali, Kode Area - No Fax, Alamat e-mail Wali, Provinsi Tempat Tinggal, Kota/Kabupaten Tempat Tinggal, Negara Tempat Tinggal, Pekerjaan Wali, Jabatan Pekerjaan, Nama Perusahaan, Pendidikan Wali, Hubungan Wali dengan Mahasiswa/i.

Pada use case diagram Penambahan Formulir, yang bertindak sebagai aktor adalah pihak admisi dan IT Directorate yang mengatur penambahan formulir melalui back end admisi online. Untuk pembuatan formulir yang baru, pihak admisi memberi field yang dibutuhkan kepada pihak IT Directorate. Pihak IT Directorate dapat melakukan analisis field yang lebih tepat untuk tahap coding. Admisi juga dapat memberikan data yang mendukung untuk pembuatan formulir baru. Testing dilakukan oleh IT Directorate. Gambar Use Case Penambahan Formulir dapat dilihat pada Gambar 3.

Pada use case diagram Pendaftaran Admisi, yang bertindak sebagai aktor adalah pendaftar yang melakukan pendaftaran secara online. Pihak pendaftar dapat memilih instansi. Dari instansi tersebut terdapat term of use yang terdapat pilihan untuk menyetujui term of use dan formulir. Pendaftar melakukan pengisian formulir yang di dalamnya terdapat halaman rekomendasi, halaman pembelian formulir, halaman kedua yang berisi rincian pendaftar, dan halaman ketiga yang berisi biodata ayah, ibu, dan wali. Gambar Use Case ini dapat dilihat pada Gambar 4.

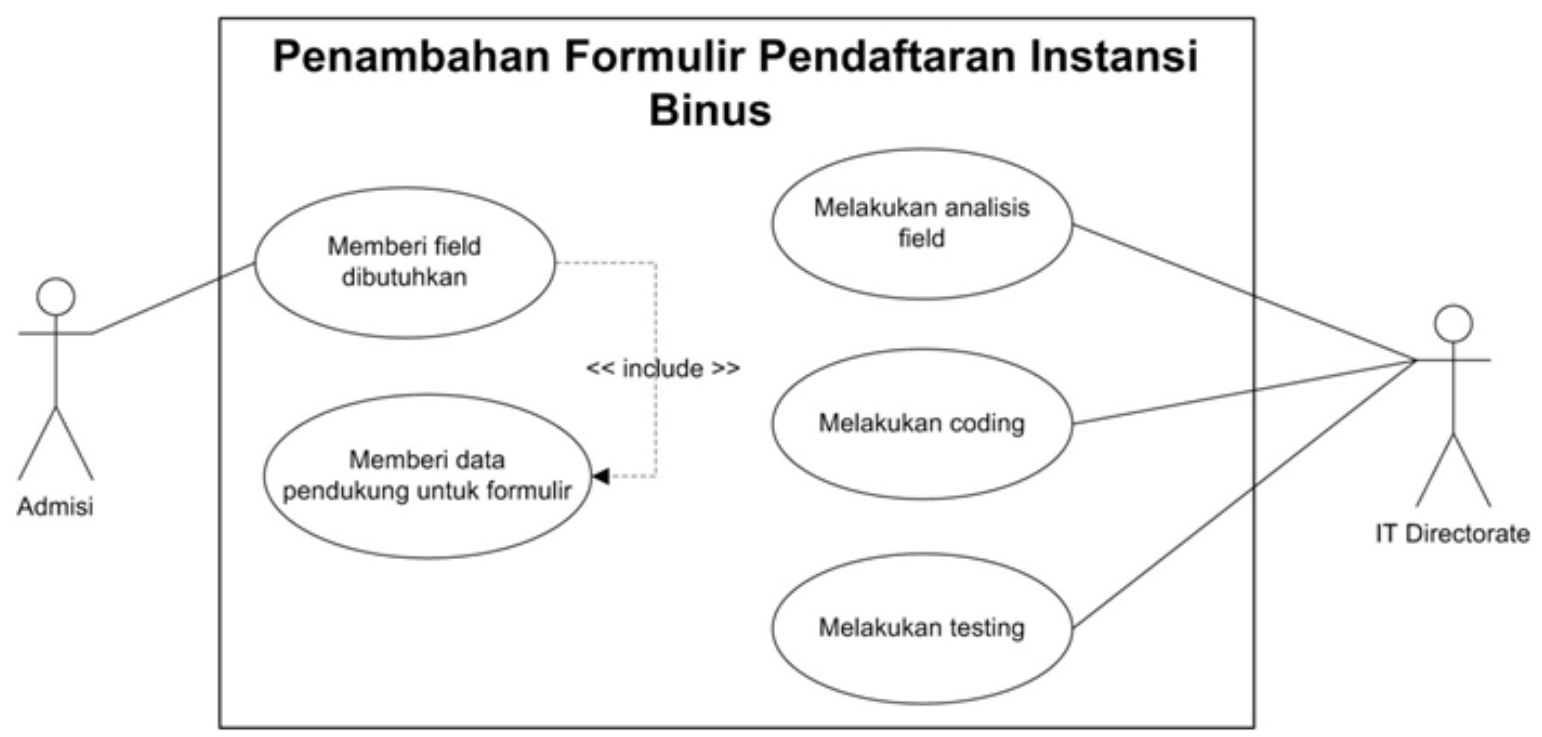

Gambar 3. Use case diagram penambahan formulir (sistem yang sedang berjalan).

\section{Permasalahan yang Dihadapi dan Alternatif Pemecahan Masalah}

Berdasarkan analisis permasalahan yang dilakukan, ditemukan masalah yang dihadapi pada sistem Admisi online saat ini, yaitu: Penambahan formulir pendaftaran online instansi Binus dilakukan dengan coding. Dan permasalah lainnya adalah Pengisian formulir yang kurang efektif dan efisien.

Alternatif pemecahan masalah yang dilakukan adalah dengan menambahkan sistem penambahan dan pengaturan formulir instansi Binus pada back end admisi online Binus. Proses ini dilakukan dengan mengelompokkan field-field yang ada berdasarkan tujuannya. Misalnya field nama 
sekolah SMTA, alamat sekolah SMTA, dan kota tempat SMTA dikelompokkan ke dalam widget Asal sekolah. Setelah dikelompokkan, proses penambahan formulir dilakukan dengan cara memilih widgetwidget dan memasukkan seluruh informasi yang dibutuhkan oleh formulir tersebut.

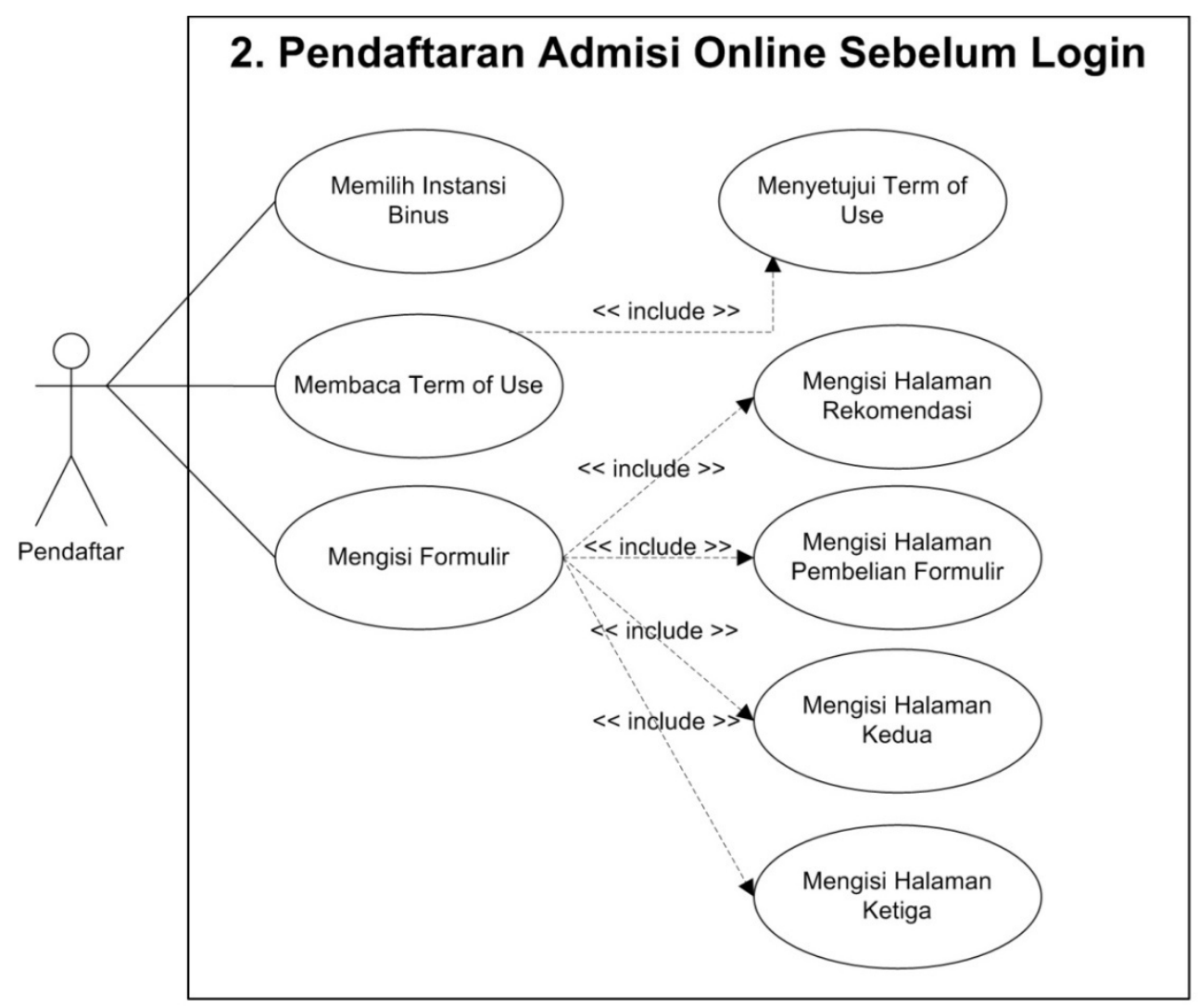

Gambar 4. Use case diagram pendaftaran admisi online sebelum login (sistem yang sedang berjalan).

\section{Perancangan Proses Penambahan Formulir untuk Instansi Binus Baru}

Perancangan penambahan formulir terdapat dua langkah utama yang dibuat. Pertama, melakukan analisis terhadap field dari formulir pendaftaran pada setiap instansi Binus. Analisis yang dilakukan menghasilkan kumpulan field yang digolongkan menjadi widget. Widget yang dihasilkan terdiri dari: (1) Asal Sekolah, Widget ini bertujuan untuk menerima informasi asal sekolah dari pendaftar. Widget tersebut terdiri dari field: Nama Sekolah SMTA, Alamat Sekolah SMTA, dan Kota tempat SMTA; (2) Biodata Diri, Widget ini bertujuan untuk menerima informasi biodata pendaftar. Widget tersebut terdiri dari field: Gelombang, Jenis Pendaftaran, Lokasi, Nama Calon Mahasiswa, Tempat Lahir, Tanggal Lahir, Alamat E-mail, Jenis Kelamin, Kewarganegaraan, Agama, Status Kerja, Status Perkawinan, Alamat Lengkap, Nomor Rumah, RT, RW, Kota, Kode Pos, No. Telp, Mobile Number 1, Mobile Number 2, Mobile Number 3, Nama Ayah, Nama Ibu, dan Nama Wali; (3) Pekerjaan, Widget ini bertujuan untuk menerima informasi pekerjaan dari pendaftar. Widget tersebut terdiri dari field: Status Kerja, Jabatan, Nama Perusahaan, Alamat Perusahaan, Nomor Perusahaan, RT, RW, Kota, Kode Pos, No Telp, No Fax, dan Alamat Penyuratan; (4) Peminatan, Widget ini bertujuan untuk menerima informasi jenjang studi yang akan diambil oleh pendaftar. Widget tersebut terdiri dari field: Jenis SMTA, Fakultas, Jurusan, Jenjang, Peminatan, Shift Kuliah, dan Lokasi Perkuliahan; (5) Pendidikan Formal, Widget ini bertujuan untuk menerima informasi pendidikan formal yang telah ditempuh oleh pendaftar. Widget tersebut terdiri dari field: Nama Universitas, 
Program Studi, Gelar Keserjanaan, Tahun Kelulusan, dan IPK S1; (6) Pengalaman Kerja, Widget ini bertujuan untuk menerima informasi pengalaman kerja dari pendaftar. Widget tersebut terdiri dari field: Nama Perusahaan, Posisi, Bagian, Tingkat, dan Tahun Kerja; (7) Tes Inggris, Widget ini bertujuan untuk menerima informasi hasil tes Bahasa Inggris yang telah dicapai oleh pendaftar. Widget tersebut terdiri dari field: Jenis Tes Inggris 1, Nilai TOEFL, Nama Institusi, Jenis Tes Inggris 2, Nilai TWE, Nama Institusi, Jenis Tes Inggris 3, Nilai IELTS, dan Nama Institusi.

Selanjutnya, melakukan pengelompokkan widget yang akan ditampilkan. Pengelompokkan tesebut disesuaikan dengan waktu pengisiannya yaitu sebelum login dan setelah login (Tabel 2). Widget-widget tersebut dibagi agar pengisian formulir pada saat sebelum login menjadi lebih ringkas. Pada widget biodata ayah, biodata ibu, dan biodata wali data yang didapatkan jika pendaftar belum menjadi Binusian tidak akan berguna. Hal ini berlaku untuk semua instansi Binus.

Setelah itu, hasil dari widget-widget tersebut dikelompokkan menjadi formulir yang disesuaikan dengan instansi Binus yang tersedia (Tabel 3). Kemudian berdasarkan pengelompokkan tersebut, penulis membuat back end yang mengatur penambahan ataupun pengubahan formulir instansi Binus. Berikut detail formulir yang pengisiannya sebelum login berdasarkan instansi Binus: (1) Binus Regular - pada instansi ini terdapat widget: Biodata Diri, Peminatan, dan Asal Sekolah; (2) Binus International - pada instansi ini terdapat widget: Biodata Diri, Peminatan, Asal Sekolah, dan Tes Inggris; (3) Binus Online Learning - pada instansi ini terdapat widget: Biodata Diri, Peminatan, Pekerjaan, Pendidikan Formal, dan Pengalaman Kerja; (4) Binus Magister Management - pada instansi ini terdapat widget: Biodata Diri, Peminatan, Pekerjaan, dan Pengalaman Kerja.

Tabel 2

Pembagian Widget Berdasarkan Waktu Pengisian

\begin{tabular}{lcc}
\hline \multicolumn{1}{c}{ Widget } & Diisi Sebelum Login & Diisi Setelah Login \\
\hline Asal Sekolah & $\sqrt{ }$ & \\
\hline Biodata Diri & $\sqrt{ }$ & \\
\hline Biodata Ayah & & $\sqrt{ }$ \\
\hline Biodata Ibu & & \\
\hline Biodata Wali & $\sqrt{ }$ \\
\hline Pekerjaan & $\sqrt{ }$ & \\
\hline Peminatan & $\sqrt{ }$ & \\
\hline Pendidikan Formal & $\sqrt{ }$ & \\
\hline Pengalaman Kerja & $\sqrt{ }$ \\
\hline Tes Inggris & $\sqrt{ }$
\end{tabular}

Tabel 3

Pembagian Penggunaan Widget Berdasarkan Instansi Binus

\begin{tabular}{|c|c|c|c|c|c|}
\hline Widget & $\begin{array}{c}\text { Binus } \\
\text { Regular }\end{array}$ & $\begin{array}{c}\text { Binus } \\
\text { International }\end{array}$ & $\begin{array}{c}\text { Binus Online } \\
\text { Learning }\end{array}$ & $\begin{array}{c}\text { High School } \\
\text { Enrichment } \\
\text { Program } \\
\end{array}$ & $\begin{array}{c}\text { Binus } \\
\text { Magister } \\
\text { Management }\end{array}$ \\
\hline Asal Sekolah & $\sqrt{ }$ & $\sqrt{ }$ & & & \\
\hline Biodata Diri & $\sqrt{ }$ & $\sqrt{ }$ & $\sqrt{ }$ & $\sqrt{ }$ & $\sqrt{ }$ \\
\hline Pekerjaan & & & $\sqrt{ }$ & $\sqrt{ }$ & $\sqrt{ }$ \\
\hline Peminatan & $\sqrt{ }$ & $\sqrt{ }$ & $\sqrt{ }$ & & $\sqrt{ }$ \\
\hline Pendidikan Formal & & & $\sqrt{ }$ & $\sqrt{ }$ & \\
\hline Pengalaman Kerja & & & $\sqrt{ }$ & $\sqrt{ }$ & $\sqrt{ }$ \\
\hline Tes Inggris & & $\sqrt{ }$ & & & \\
\hline
\end{tabular}


Pada rich picture penambahan formulir baru (Gambar 5) terdapat 11 langkah yang terdiri dari: (1) Manager Marketing menambahkan jenis formulir baru untuk instansi Binus yang dibuat. Penambahan ini terjadi pada Sistem yang langsung berhubungan dengan database admisi; (2) Marketing melakukan pengisian harga formulir baru; (3) Marketing menambahkan gelombang pendaftaran untuk instansi baru; (4) Marketing menentukan tanggal ujian dari instansi baru; (5) Marketing menentukan shift kuliah instansi baru seperti shift pagi atau shift malam; (6) Marketing menentukan jurusan dari pendidikan formal yang sesuai dengan persyaratan masuk; (7) Marketing memberi hak akses admin pada pihak marketing lainnya untuk mengatur formulir instansi baru melalui back end admisi; (8) Admin marketing menambahkan prosedur seperti alamat admisi dan petunjuk dokumen untuk pendaftar yang muncul pada halaman konfirmasi pendaftaran; (9) Admin marketing menambahkan term of use sebagai syarat pengisian formulir instansi baru; (10) Admin marketing mengatur widget pengisian yang sesuai dengan hasil analisis widget yang diperlukan untuk formulir instansi baru; (11) Admin marketing mengatur data konfirmasi yang berhubungan dengan formulir instansi baru. Data konfirmasi tersebut terdiri dari email pengirim konfirmasi, yahoo messenger, id biller, upload foto ATM kode biller, upload attachment, upload logo Binus. Setelah 11 langkah tersebut selesai dilakukan, pendaftaran dari instansi Binus yang baru segera dapat dijalankan.

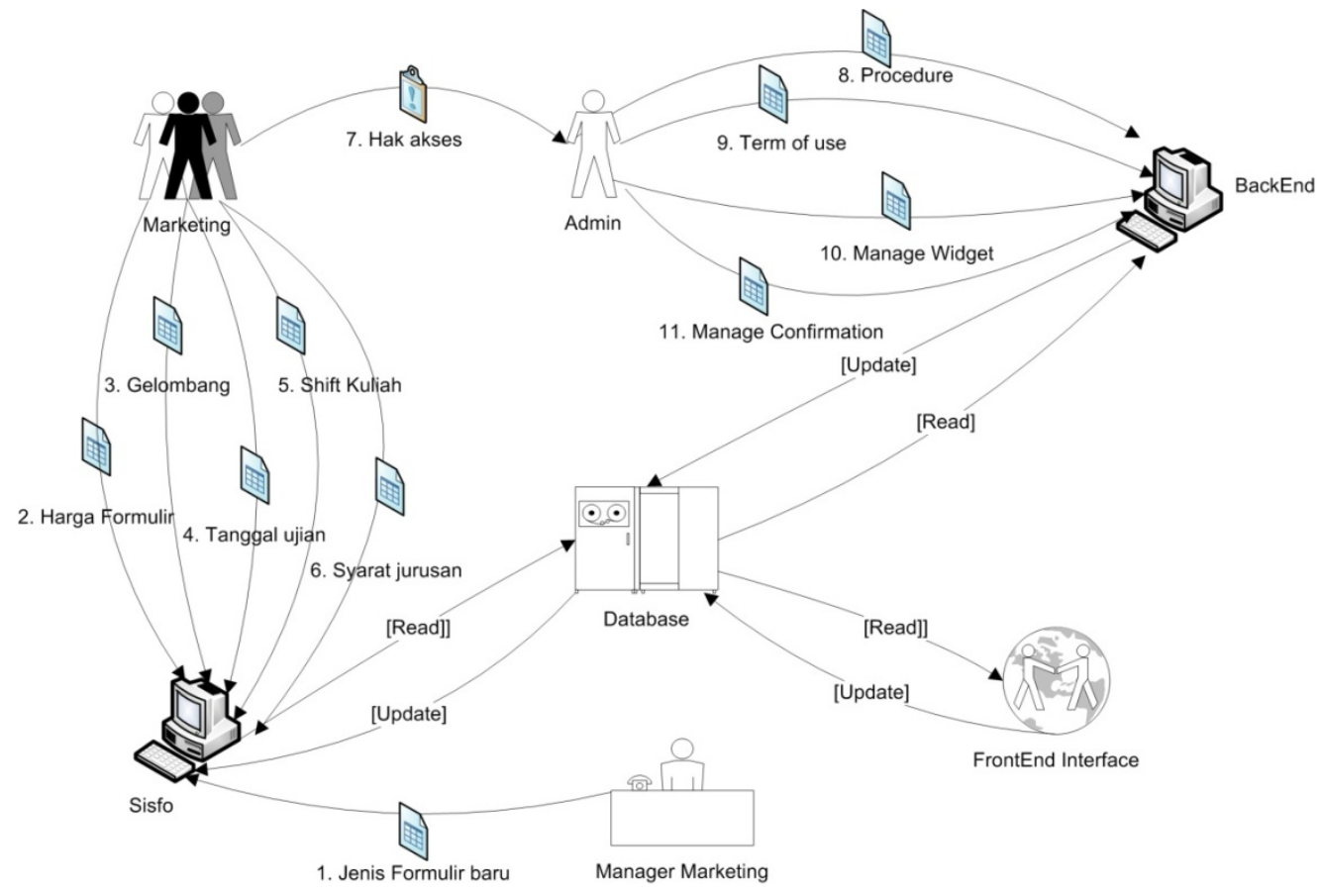

Gambar 5. Rich picture langkah-langkah penambahan formulir baru.

Pada use case diagram Penambahan Formulir Baru (Gambar 6), yang bertindak sebagai aktor adalah pihak admisi yang mengatur penambahan formulir melalui back end admisi online.Aktor dapat melakukan melakukan mengatur term of use, mengatur widget, menambahkan email konfirmasi, menambahkan yahoo messenger, menambahkan kode biller ATM, meng-upload foto kode biller ATM, meng-upload attachment surat perjanjian, meng-upload logo instansi, menambahkan kode payment visa, menambahkan alamat admisi, menambahkan prosedur tambahan. Pada use case diagram Daftar Online, yang bertindak sebagai aktor adalah pendaftar yang melakukan pendaftaran secara online. Aktor dapat melakukan memilih instansi Binus, menyetujui term of use, mengisi halaman utama formulir. 


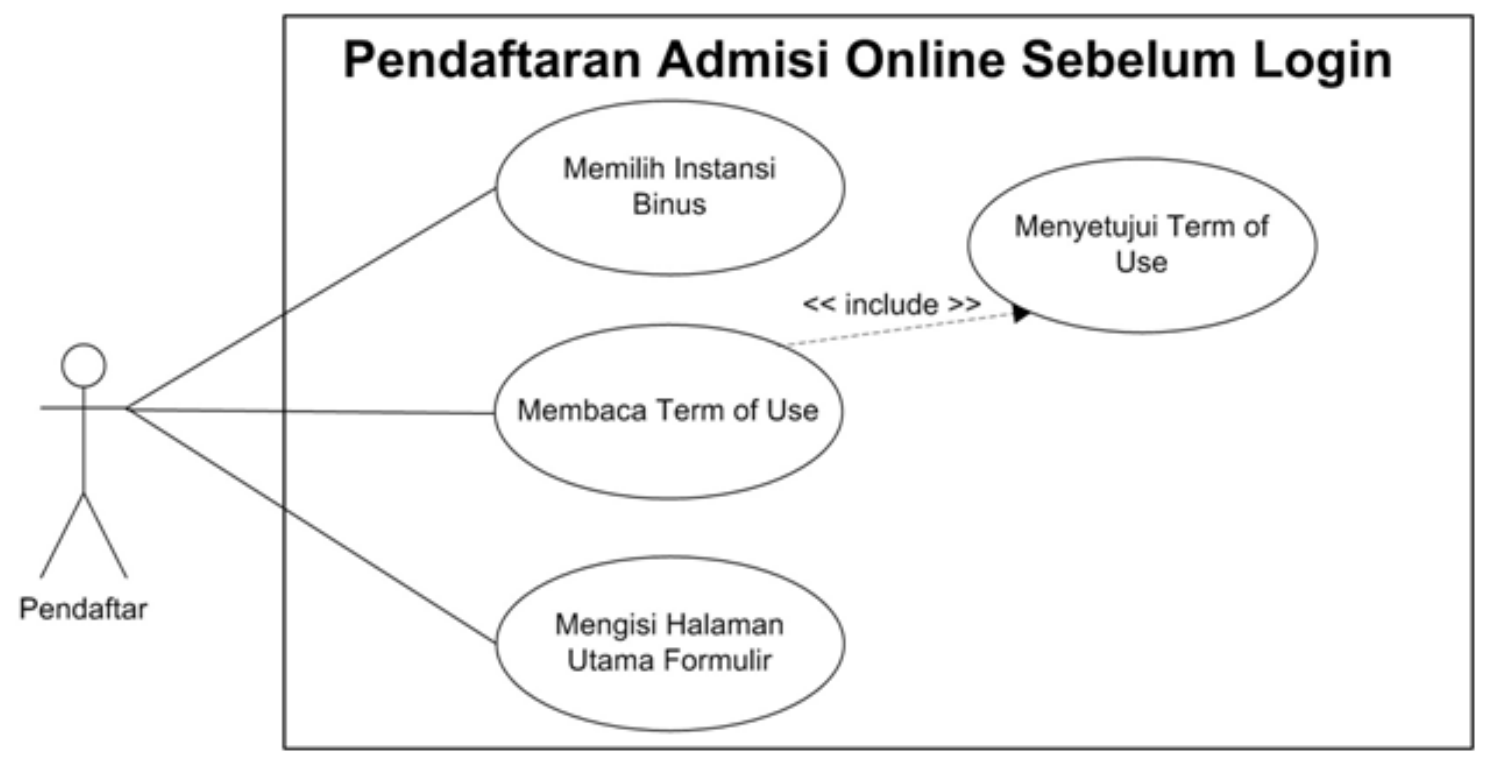

Gambar 6. Use case diagram pendaftaran pada formulir admisi online.

Setelah pengembangan sistem back end untuk penambahan formulir pendaftaran instansi Binus baru, waktu yang dibutuhkan untuk penambahan formulir menjadi lebih cepat. Untuk penambahan jenis formulir baru tetap dilakukan oleh Manager Marketing. Kemudian staff Marketing menganalisis widget yang diperlukan untuk formulir pendaftaran instansi Binus yang baru. Setelah itu melakukan penambahan rincian dari pendaftaran dan mengatur widget dari hasil analisis. Staff Marketing dapat langsung melakukan testing pada formulir yang dibuat. Berikut waktu yang diperlukan untuk melakukan penambahan formulir pada sistem yang baru (Tabel 4):

Tabel 4

Perbandingan Prosedur Penambahan Formulir

\begin{tabular}{ccccc}
\hline \multirow{2}{*}{ Proses } & \multicolumn{2}{c}{ Waktu yang Dibutuhkan } & \multicolumn{2}{c}{ Pelaksana } \\
\cline { 2 - 5 } & Sistem Berjalan & Sistem Baru & Sistem Berjalan & Sistem Baru \\
\hline $\begin{array}{c}\text { Penambahan } \\
\text { instansi baru }\end{array}$ & \pm 10 menit & \pm 10 menit & Manager Marketing & Manager Marketing \\
\hline $\begin{array}{c}\text { Analisis field yang } \\
\text { dibutuhkan }\end{array}$ & $\pm 1,5$ minggu & - & $\begin{array}{c}\text { IT Directorate dan } \\
\text { Marketing }\end{array}$ & - \\
\hline $\begin{array}{c}\text { Analisis widget } \\
\text { yang dibutuhkan }\end{array}$ & - & $\pm 1,5$ minggu & - & Marketing \\
\hline Design & $\pm 0,5$ minggu & - & IT Directorate & - \\
\hline Coding & $\pm 1,5$ bulan & - & IT Directorate & - \\
\hline $\begin{array}{c}\text { Penambahan } \\
\text { formulir melalui } \\
\text { back end }\end{array}$ & - & \pm 10 menit & - & Marketing \\
\hline \begin{tabular}{c} 
Testing \\
\hline
\end{tabular} & \pm 2 minggu & \pm 2 minggu & IT Directorate & Marketing \\
\hline
\end{tabular}


Dapat dilihat dari tabel di atas, penambahan formulir lama membutuhkan waktu \pm 10 menit dalam lingkup sudah dilakukan analisis widget yang diperlukan untuk formulir instansi Binus yang baru. Hal ini jauh lebih cepat dibandingkan dengan sistem yang lama di mana melakukan coding yang membutuhkan waktu selama $\pm 1,5$ bulan.

Setelah pemindahan field pada biodata ayah, biodata ibu, biodata wali, dan dihilangkannya biodata pembeli, waktu yang diperlukan untuk pengisian formulir menjadi lebih cepat. Sebagai evaluasi, formulir pendaftaran yang diambil adalah Binus Regular.

\section{PENUTUP}

Berdasarkan hasil penelitian yang dilakukan pada admisi online Binus University, dapat disimpulkan bahwa Penambahan formulir pendaftaran admisi online menjadi lebih cepat dengan adanya back end yang mengatur pembuatan formulir instansi baru. Waktu yang diperlukan untuk melakukan pendaftaran pada admisi online menjadi lebih cepat dan tingkat kesalahan yang mungkin dilakukan oleh calon pendaftar menjadi berkurang. Adapun saran dari untuk penelitian lebih lanjut adalah merancang dan mengembangkan aplikasi mobile untuk admisi online, serta merancang dan mengembangkan pembuatan widget melalui back end.

\section{DAFTAR PUSTAKA}

Bennett, S., Skelton, J., \& Lunn, S. (2005). Schaum's Outlines UML (2nd edition). Washington, D.C.: McGraw-Hill.

Connolly, T. M., \& Carolyn E. B. (2004). Database Systems: A Practical Approach to Design, Implementation, and Management (4th edition). Harlow: Addison Wesley.

Hoffer, J.A., Prescott, M. B., \& Topi, H. (2009). Modern Database Management (9th edition). New Jersey: Pearson Prentice Hall.

Mathiassen, Lars, et al. (2000). Object Oriented Analysis \& Design (1st edition). Aalborg, Denmark: Makro Publishing APS.

Pressman, R. S. (2006). Software Engineering: A Practitioner's Approach (6th edition). New York: McGraw-Hill. 